\begin{tabular}{|l|l|l||}
\hline \multicolumn{2}{|c|}{ PublisherInfo } \\
\hline \hline PublisherName & $:$ & BioMed Central \\
\hline \hline PublisherLocation & $:$ & London \\
\hline \hline PublisherImprintName & $:$ & BioMed Central \\
\hline \hline
\end{tabular}

\title{
Science slowed by fires
}

\begin{tabular}{|l|l|l||}
\hline \multicolumn{2}{|c|}{ ArticleInfo } \\
\hline \hline ArticleID & $:$ & 4870 \\
\hline \hline ArticleDOI & $:$ & $10.1186 /$ gb-spotlight-20031031-02 \\
\hline \hline ArticleCitationID & $:$ & spotlight-20031031-03 \\
\hline \hline ArticleSequenceNumber & $:$ & 222 \\
\hline \hline ArticleCategory & $:$ & Research news \\
\hline ArticleFirstPage & $:$ & 1 \\
\hline \hline ArticleLastPage & $:$ & 3 \\
\hline \hline & & RegistrationDate : 2003-10-31 \\
ArticleHistory & $:$ & OnlineDate \\
\hline \hline ArticleCopyright & $:$ & BioMed Central Ltd2003 \\
\hline \hline ArticleGrants & $:$ & \\
\hline \hline ArticleContext & $:$ & 130594411 \\
\hline \hline
\end{tabular}


Eugene Russo

Email: erusso@the-scientist.com

Poor air quality, rather than flames, has been the primary problem affecting academic research centers and biotechs in the San Diego area, as massive wild fires swept through the region this week, killing 20 people and destroying more than 2600 homes.

The University of California at San Diego, the Salk Institute for Biological Studies, the Scripps Research Institute, and several biotechs in the area closed down for 2 to 3 days, starting Monday (October 27), due to extremely poor air quality. San Diego's mayor also requested office closures to keep roads clear and maximize fire trucks' access to affected areas. Air quality was much improved on Wednesday (October 29) because of shifting winds.

Salk Institute President Richard Murphy said that employees who did come to work - to feed and care for experimental animals, for example - had to wear face masks to protect against the visibly smoky air that circulated through the building.

Like other research centers in the area, Salk reported no significant damage to experiments or equipment. Like several other institutions, however, Salk did request and receive a 2-week extension for a November 1 National Institutes of Health grant application deadline.

Though the flames did not threaten research facilities, many employees' families left their homes because of the fires, which have so far burned across an 1500 square mile area. Salk offered to help any displaced employees with housing but has had no takers thus far, Murphy said, although several employees have offered coworkers in need a place to stay.

At Gen-Probe, a 650-employee biotech in Mira Mesa, at least two employees' families lost homes. On Sunday (October 26), Gen-Probe's Chairman and Chief Executive Officer Henry Nordhoff happened to run into his company's vice president of business development, whose family had been evacuated. Nordhoff took them in and recalled how later that day, as they watched television coverage together, they were stunned to see his colleague's home spared while houses all around it were burned to the ground.

Nordhoff also noted a positive outcome of the work disruption: his company decided to donate several hundred unused turkey dinners to displaced persons after a company Halloween party was canceled. After offering them to the Red Cross at one site, and being turned down because McDonald's and Outback restaurants had already donated lunch and dinner, Gen-Probe employees found several hundred very grateful evacuees at a firehouse in the town of Alpine.

"They went nuts," said Nordhoff, referring to the evacuees. "They all grabbed them, gave [the GenProbe employees] hugs. We even got a proclamation from the mayor of the town."

All of the businesses and institutions contacted by us were back to full staff and regular hours by Thursday (October 30). 


\section{References}

1. University of California, San Diego, [http://www.ucsd.edu/]

2. Salk Institute for Biological Studies, [http://www.salk.edu/]

3. Scripps Research Institute, [http://www.scripps.edu/]

4. Gen-Probe, [http://www.gen-probe.com/]

This PDF file was created after publication. 